\title{
Parametric Optimization of Wire Cut EDM Process on 'AISID3 Steel' using Genetic Algorithm and Grey Relation Analysis
}

\author{
D. Vishnuvardhan Reddy ${ }^{1}$ \\ Dept of Mechanical Engineering \\ AITS, Rajampet, (A.P), INDIA
}

\author{
Dr. P.V. Sanjeeva Kumar ${ }^{2}$ \\ Dept of Mechanical Engineering \\ AITS, Rajampet, (A.P), INDIA
}

\begin{abstract}
The manufacturing industries are continuously seeking for new and better machining operations in order to achieve the desired profile or contour of their machining parts. In view of this requirement, at present we focused on Wire Electrical Discharge Machining process. The Wire Electric Discharge Machining (WEDM) is a non-traditional process of material from conductive material to produce parts with intricate shape and profiles. Machine trade has created exponential growth in its producing capabilities in last decade however still machine tools don't seem to be used at their full potential. within the gift work, a trial has been created to optimize the machining conditions for surface roughness supported (L9 Orthogonal Array) Taguchi methodology. Experiments were carried out under varying pulse-on-time, pulse-off-time, servo control, and wire feed. An orthogonal array, the genetic algorithm (GA) and grey relational analysis (GRA) were employed to the study the surface roughness in the WEDM of AISI D3 Steel. It was determined that the discharge current was the foremost prestigious factors on the surface roughness. To validate the study, confirmation experiment has been dispensed at optimum set of parameters and expected results are found to be in sensible agreement with experimental findings.
\end{abstract}

Key words: WEDM, Surface roughness, Discharge current, Genetic Algorithm, Grey Relation Analysis

\section{INTRODUCTION}

Need for Unconventional Machining Processes was extremely hard and brittle materials or Difficult to machine material are difficult to Machine by traditional machining processes. once the work piece is simply too versatile or slender to support the cutting or grinding forces once the form of the half is simply too complicated. many sorts of non-traditional machining processes are developed to fulfill additional needed machining conditions. once these processes square measure used properly, they provide several blessings over non-traditional machining processes. The wire EDM is one of the vital non-conventional machining techniques. The effect of process parameters on the quality of machining especially surface roughness is much more crucial. Brajesh Kumar Lodhi et.al.[1] studied on optimization of the machining conditions for surface roughness based on (L9 Orthogonal Array) Taguchi methodology. Experiments were distributed below variable pulse-on-time, pulse-off-time, peak current, and wire feed. Jyosha Joshi et.al.[2] Investigated on optimizing the machining parameter of wire electrical discharge machining
(WEDM) for multiple performance characteristics on D3 tool steel using principal component analysis (PCA). Shivade et.al.[3] performed wire discharge machining of D3 alloy steel and Influence of pulse-on time, pulse-off time, peak current and wire speed square measure investigated for MRR, dimensional deviation, gap current and machining time, throughout convoluted machining of D3 alloy steel. Pankaj et.al.[4] are studied the effect of various process parameters such as pulse on time, pulse off time and current for high carbon high chromium cold work tool steel (D2). The experiment has been completed with the help of Design of experiment by Taguchi method is applied to create an orthogonal array of input variables using the ANOVA. M. Siva Kumar et.al.[5] Optimum machining parameter for the wire electrical discharge machining of AISI D3 steel of two different thickness $(50 \mathrm{~mm} \& 75 \mathrm{~mm})$. Omkar Kulkarni et.al.[6] The experimentation has been completed with the help of Taguchi's L25 Orthogonal Array. Grey Wolf Optimizer (GWO) algorithm is stimulated by grey wolves. Mangesh et.al.[7] Performed CNC wire electrical discharge machining (WEDM) of $\mathrm{Al} 2124 \mathrm{SiCp}$ Metal Matrix Composite (MMC) is analyzed by using dimensional analysis approach (DA) and artificial neural network (ANN). The various investigations [8-12] are carried out on the optimizations of process parameters by using grey analysis and genetic algorithms. Pratik A. Patil et.al.[13] investigated effect of parameter on machining of AISI D2 cold work steel through wire cut EDM. This research deals with Response Surface Methodology approach for maximizing the material removal rate in wire electrical discharge machining. $M$. Durairaj et.al.[14] investigated effect of parameter on machining of SS304 through wire cut EDM. Amitesh Goswami et.al.[15] Analysis trim cut machining and surface integrity of Nimonic 80A alloy using wire cut EDM with three levels of input parameters. Somvir Singh Nain et.al.[16] Modeling and optimization of process variables of wire-cut electric discharge machining of super alloy UdimetL605. In this paper, an attempt is made to investigate the influence of WEDM process parameters on the performance measures of surface finish and cutting speed while machining of AISID3 STEEL with three levels of process parameters Pulse-on time, Pulse-off time, Wire feed \& servo control. 


\section{SELECTION OF MATERIAL}

AISID3 steel, also known as 1.2080 (werkstoff), it is an air hardening, high-carbon, high-chromium tool steel It displays glorious abrasion/wear resistance and has sensible dimensional stability and high compressive strength. it's heats treatable and can provide a hardness within the vary 58-64 HRC. because of its abrasion resistance within the hardened condition, D3 machining ought to be restricted to finished grinding. The physical and chemical properties of a material are given in Tables $1 \& 2$.

TABLE 1: PHYSICAL PROPERTIES

\begin{tabular}{|l|l|l|}
\hline S.No & \multicolumn{1}{|c|}{ Name of the property } & \multicolumn{1}{c|}{ Values } \\
\hline 1 & density & $.7 \times 1000 \mathrm{~kg} / \mathrm{m}^{3}$ or $0.278 \mathrm{lb} / \mathrm{in}^{3}$ \\
\hline 2 & Melting point & $1421^{\circ} \mathrm{C}$ or $2590^{\circ} \mathrm{F}$ \\
\hline 3 & $\begin{array}{l}\text { Co-efficient of Thermal } \\
\text { Expansion }\end{array}$ & $12 \times 10-6 /{ }^{\circ} \mathrm{C}$ or $20-100^{\circ} \mathrm{C}$ \\
\hline 4 & Modulus of elasticity & $190-210 \mathrm{Gpa}$ or $27557-304547 \mathrm{ksi}$ \\
\hline
\end{tabular}

TABLE 2 : CHEMICAL COMPOSITION

\begin{tabular}{|l|l|l|}
\hline S.No & \multicolumn{1}{|c|}{ Name of the element } & \multicolumn{1}{c|}{ Values } \\
\hline 1 & Carbon $(\mathrm{C})$ & $2.00-2.35 \%$ \\
\hline 2 & Manganese $(\mathrm{Mn})$ & $0.60 \%$ \\
\hline 3 & Silicon $(\mathrm{Si})$ & $0.60 \%$ \\
\hline 4 & Sulfur $(\mathrm{S})$ & $0.03 \%$ \\
\hline 5 & Chromium $(\mathrm{Cr})$ & $11.00-13.50 \%$ \\
\hline 6 & Nickel $(\mathrm{Ni})$ & $0.30 \%$ \\
\hline 7 & Vanadium $(\mathrm{V})$ & $1.00 \%$ \\
\hline 8 & Phosphorus $(\mathrm{P})$ & $0.03 \%$ \\
\hline 9 & Copper $(\mathrm{Cu})$ & $0.25 \%$ \\
\hline 10 & Tungsten $(\mathrm{W})$ & $1.00 \%$ \\
\hline
\end{tabular}

\section{METHODOLOGY}

The following procedure is adopted to pursue the optimization of the process parameters.

- Selection of Material: AISI D3 steel

- Identifying and selection of various process parameters influencing the machining process

- Finalizing the levels and preparing a design of experiments plan by using Minitab software

- Conduct the experiment based on design of experiments; calculate the surface roughness and cutting speed

- Optimal machining parameters were determined by the grey relational grade obtained from the grey relational analysis and genetic algorithm for multi- performance characteristics for surface roughness and material removal rate

- A confirmation experiments was conducted by setting the process parameters at optimum level. The order of importance of the controllable factors to the surface roughness and material removal rate are estimated.

\section{A. Grey Relational Analysis}

Grey relational analysis is an impacting measuring technique in gray system theory that analyzes unsure relations between one main issue and every one the opposite factors in a very given system. In the case when experiments are ambiguous or when the experimental method cannot be carried out exactly, grey analysis helps to compensate for the shortcomings in statistical regression . Grey relational analysis is actually a quantity of the absolute value of the data variance between sequences, and it could be used to degree the approximate correlation between sequences.

\section{B. Genetic Algorithm}

Genetic algorithmic rules area unit a kind of optimization algorithm, which means they're accustomed realize the most or minimum of a perform. typically speaking, genetic algorithms area unit simulations of evolution, of what kind ever. In most cases, however, genetic algorithms area unit nothing else than probabilistic optimization strategies that area unit supported the principles of evolution

\section{Definition}

Assume $\mathrm{S}$ to be a set of strings (in non-trivial cases with some underlying grammar). Let $\mathrm{X}$ be the search space of an optimization problem as above, then a function

$$
\begin{aligned}
& \mathrm{c}: \mathrm{X} \rightarrow \mathrm{S} \\
& \mathrm{x} \rightarrow \mathrm{c}(\mathrm{x})
\end{aligned}
$$

is called coding function. Conversely, a function

$\tilde{c}: S \rightarrow X$

$\mathrm{S} \rightarrow \tilde{\mathrm{c}(\mathrm{s})}$

is called decoding function.

In practice, coding and decoding functions, which have to be specified depending on the needs of the actual problem, are not necessarily objective. However, it is in most of the cases useful to work with injective decoding functions (we will see examples soon).

Moreover, the following equality is often supposed to be satisfied:

$$
\left(\mathrm{c} \text { o } \mathrm{c}^{\mathrm{c}}\right) \equiv \mathrm{idS}
$$

Finally, we can write down the general formulation of the encoded maximization problem:

Find an $\mathrm{s} 0 \in \mathrm{S}$ such that $\tilde{\mathrm{f}}=\mathrm{f}$ o $\tilde{c}$ is as large as possible.

\section{Algorithm}

$\mathrm{t}:=0$

Compute initial population $\mathrm{B}_{0}$;

WHILE stopping condition not fulfilled DO

BEGIN

Select individuals for reproduction;

create off springs by crossing individuals;

eventually mutate some individuals;

compute new generation

\section{EXPERIMENTAL WORK}

Experiment has been done on ELECTRONICA SPRINTCUT wire electric discharge machine (WEDM) as shown in the figure 4.1. In this work the work piece material has been taken as a flat having dimensions $150 \times$ $50 \times 7 \mathrm{~mm}$ thickness. Experiments were conducted on AISI D3 steel material and mounted on a WEDM machine tool as shown in figure in 1 . the cutting areas of the specimens are $10 \times 15 \times 7 \mathrm{~mm}$ thickness. In the current work, four process parameters such as pulse on time (Ton), pulse off time (Toff), wire feed rate (WF) and servo control (C/S) were selected for conducting the experiments. The range of experiments was determined from the previous experiments by the MINITAB software 
based on Taguchi orthogonal array. Each process parameter was investigated at three levels to study the nonlinearity effect of parameters. The selected process parameters and their levels are given in table 3 . and machined specimens are shown in figure 2 .

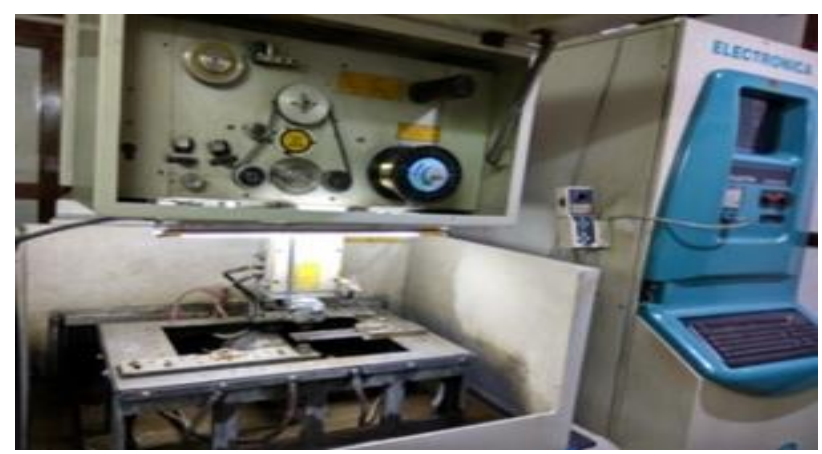

Fig .1: WEDM Setup

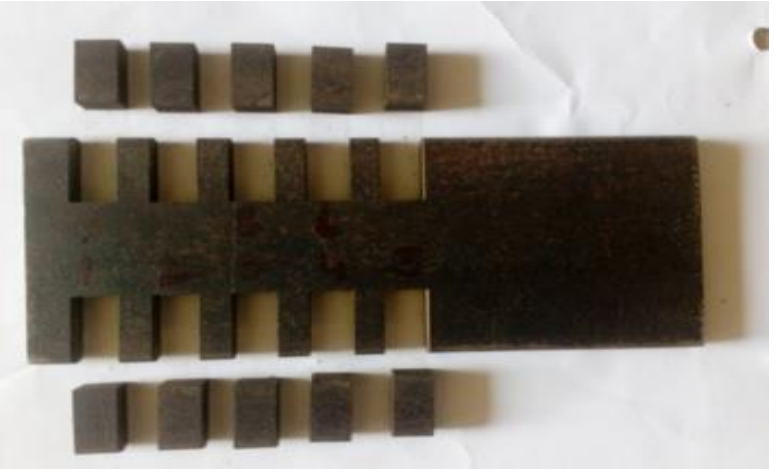

Fig .2: Machined specimens of AISI D3 steel

TABLE 3 : PROCESS PARAMETERS AND THEIR LEVELS

\begin{tabular}{|c|c|c|c|c|c|}
\hline $\begin{array}{c}\text { S. } \\
\text { No. }\end{array}$ & Process Parameter & Symbol & Leve1 & Level 2 & Leve1 3 \\
\hline 1 & Pulse on time $(\mu \mathrm{s})$ & A & 108 & 112 & 116 \\
\hline 2 & Pulse off time $(\mu \mathrm{s})$ & B & 45 & 50 & 55 \\
\hline 3 & $\begin{array}{c}\text { Wire feed rate } \\
(\mathrm{m} / \mathrm{min})\end{array}$ & $\mathrm{C}$ & 1 & 2 & 3 \\
\hline 4 & Servo control $(\%)$ & $\mathrm{D}$ & 60 & 70 & 80 \\
\hline
\end{tabular}

Experiments were conducted by using the WEDM machine on the AISI D3 steel and evaluated the surface roughness and cutting speed. The experimental values containing surface roughness and cutting speed are listed in Table 4

TABLE 4 : EXPERIMENTAL LAYOUT USING L9 ORTHOGONAL ARRAY AND EXPERIMENTAL RESULTS

\begin{tabular}{|c|c|c|c|c|c|c|}
\hline $\begin{array}{c}\text { S. } \\
\text { No }\end{array}$ & $\begin{array}{c}\text { Pulse } \\
\text { on } \\
\text { time } \\
(\boldsymbol{\mu s})\end{array}$ & $\begin{array}{c}\text { Pulse } \\
\text { off } \\
\text { time } \\
(\boldsymbol{\mu s})\end{array}$ & $\begin{array}{c}\text { Wire } \\
\text { feed } \\
\text { rate } \\
(\mathbf{m} / \mathbf{m i n})\end{array}$ & $\begin{array}{c}\text { Servo } \\
\text { control } \\
(\boldsymbol{\%})\end{array}$ & $\begin{array}{c}\text { Surface } \\
\text { roughness } \\
(\boldsymbol{\mu m})-\mathbf{R a}\end{array}$ & $\begin{array}{c}\text { Cutting } \\
\text { speed } \\
(\mathbf{V c}) \\
(\mathbf{m m} / \mathbf{s e c})\end{array}$ \\
\hline 1 & 108 & 45 & 1 & 60 & 1.6200 & 1.860 \\
\hline 2 & 108 & 50 & 2 & 70 & 1.5315 & 2.190 \\
\hline 3 & 108 & 55 & 3 & 80 & 1.3885 & 1.863 \\
\hline 4 & 112 & 45 & 3 & 70 & 2.5175 & 2.150 \\
\hline 5 & 112 & 50 & 1 & 80 & 3.1625 & 2.370 \\
\hline 6 & 112 & 55 & 2 & 60 & 2.5340 & 2.590 \\
\hline 7 & 116 & 45 & 3 & 80 & 2.5875 & 3.030 \\
\hline 8 & 116 & 50 & 2 & 60 & 2.6575 & 2.960 \\
\hline 9 & 116 & 55 & 1 & 70 & 2.8280 & 2.686 \\
\hline
\end{tabular}

\section{A. Grey Relational Analysis}

In the present study, the work piece surface roughness and cutting speed in different WEDM parameters are listed in Table 4. In the WEDM process, lower surface roughness and higher cutting speed are indications of better performance.

For data pre-processing in the grey relational analysis process, both surface roughness is taken as the "lower is better" (LB) and cutting speed as "Higher is better" (HB).

Let the results of nine experiments be the comparability sequences $x^{0}(k), i=1-9, k=1$.

All the sequences after data pre-processing are listed in Table 5 and denoted as $x_{*}(k)$ and $x^{*}{ }_{i}(k)$ for reference sequence and comparability sequence, respectively. The deviation sequences $\Delta_{01}$ can be calculated as follows.

TABle 5. : THE SEQUENCES AFTER DATA PRE-PROCESSING

\begin{tabular}{|c|c|c|}
\hline Experimental number & Ra & Vc \\
\hline 1 & 0.870 & 0.000 \\
\hline 2 & 0.919 & 0.282 \\
\hline 3 & 1.000 & 0.003 \\
\hline 4 & 0.364 & 0.248 \\
\hline 5 & 0.000 & 0.436 \\
\hline 6 & 0.354 & 0.624 \\
\hline 7 & 0.324 & 1.000 \\
\hline 8 & 0.285 & 0.940 \\
\hline 9 & 0.189 & 0.707 \\
\hline
\end{tabular}

$\Delta(1)=\left|x^{*}(1)-x^{*}(1)\right|=|1.000-0.919|=0.081$

$\Delta \underset{01}{01}(2)=\left|x_{0}^{*^{*}}(2)-x_{1}^{1}(2)\right|=|1.000-0.282|=0.718$

TABle 6. : The DeViation SeQuences

\begin{tabular}{|c|c|c|}
\hline Deviation Sequences & $\mathbf{\Delta 0 i}(\mathbf{1})$ & $\mathbf{\Delta 0 i}(\mathbf{2})$ \\
\hline 1. & 0.130 & 1.000 \\
\hline 2. & 0.081 & 0.718 \\
\hline 3. & 0.000 & 0.997 \\
\hline 4. & 0.636 & 0.752 \\
\hline 5. & 1.000 & 0.564 \\
\hline 6. & 0.646 & 0.376 \\
\hline 7. & 0.676 & 0.000 \\
\hline 8. & 0.715 & 0.060 \\
\hline 9. & 0.811 & 0.293 \\
\hline
\end{tabular}

The same calculation method was performed for $i=1-9$ and the results of all $\Delta_{0} \mathrm{i}$ for $\mathrm{i}=1-9$ are given in Table 6 . Using Table $6, \Delta_{\max }$ and $\Delta_{\min }$ can be found as follows:

$\Delta_{\max }=1.00, \Delta_{\min }=0.00$

If all the process parameters are of equal weighting, then $\zeta$ is 0.5 . The grey relational coefficients and grade values for each experiment of the L9 orthogonal array.

According to the performed experiment design, it is clearly observed from table 7 that the WEDM parameters' setting of experiment no.1 has the highest grey relational grade. Therefore, experiment no. 7 is the optimal machining parameters' setting for minimum surface roughness and maximum cutting speed simultaneously (i.e. the best multiperformance characteristics) among the nine experiments

TABLE 7. : GREY RELATIONAL COEFFICIENT AND GREY RELATIONAL

\begin{tabular}{|c|c|c|c|c|c|c|c|c|}
\hline \multirow{3}{*}{$\begin{array}{l}\mathbf{S} . \\
\mathbf{N} \\
\mathbf{0}\end{array}$} & & & & GRAD & & & & \\
\hline & \multirow{2}{*}{$\begin{array}{l}\text { Puls } \\
\text { e on } \\
\text { time } \\
(\mu \mathrm{s})\end{array}$} & \multirow{2}{*}{$\begin{array}{c}\text { Puls } \\
\text { e off } \\
\text { time } \\
(\mu s)\end{array}$} & \multirow{2}{*}{$\begin{array}{c}\text { Wire } \\
\text { feed } \\
\text { rate } \\
(\mathbf{m} / \mathbf{m i n})\end{array}$} & \multirow{2}{*}{$\begin{array}{c}\text { Servo } \\
\text { contr } \\
\text { ol } \\
(\%)\end{array}$} & \multicolumn{2}{|c|}{$\begin{array}{c}\text { Grey } \\
\text { relational } \\
\text { coefficient }\end{array}$} & \multirow{2}{*}{$\begin{array}{c}\text { Gray } \\
\text { Relatio } \\
\text { nal } \\
\text { Grade }\end{array}$} & \multirow[t]{2}{*}{$\begin{array}{c}\text { or } \\
\text { de } \\
\text { r }\end{array}$} \\
\hline & & & & & $\mathbf{R a}$ & Vc & & \\
\hline 1. & 1 & 1 & 1 & 1 & 0.793 & 0.333 & 0.282 & 5 \\
\hline 2. & 1 & 2 & 2 & 2 & 0.861 & 0.411 & 0.318 & 4 \\
\hline
\end{tabular}




\begin{tabular}{|l|l|l|l|l|l|l|l|l|}
\hline 3. & 1 & 3 & 3 & 3 & 1.000 & 0.334 & 0.333 & 2 \\
\hline 4. & 2 & 1 & 3 & 2 & 0.440 & 0.399 & 0.210 & 8 \\
\hline 5. & 2 & 2 & 1 & 3 & 0.333 & 0.470 & 0.201 & 9 \\
\hline 6. & 2 & 3 & 2 & 1 & 0.436 & 0.571 & 0.252 & 7 \\
\hline 7. & 3 & 1 & 3 & 3 & 0.425 & 1.000 & 0.356 & 1 \\
\hline 8. & 3 & 2 & 2 & 1 & 0.411 & 0.893 & 0.326 & 3 \\
\hline 9. & 3 & 3 & 1 & 2 & 0.381 & 0.630 & 0.253 & 6 \\
\hline
\end{tabular}

TABLE 8. : THE RESPONSE TABLE FOR GREY RELATIONAL GRADE

\begin{tabular}{|c|c|c|c|c|}
\hline \multirow{2}{*}{$\begin{array}{c}\text { WEDM } \\
\text { machining } \\
\text { parameters }\end{array}$} & \multicolumn{3}{|c|}{$\begin{array}{c}\text { Average grey relational grade by factor } \\
\text { level }\end{array}$} & \multirow{2}{*}{ Max-min } \\
\cline { 2 - 4 } & Level 1 & Level 2 & Level 3 & \\
\hline $\mathrm{A}$ & .311 & .221 & $.312^{*}$ & 0.091 \\
\hline $\mathrm{B}$ & $.283^{*}$ & .282 & .279 & 0.004 \\
\hline $\mathrm{C}$ & .245 & .299 & $.300^{*}$ & 0.055 \\
\hline $\mathrm{D}$ & .287 & .260 & $.297^{*}$ & 0.037 \\
\hline
\end{tabular}

* indicates the optimum value

In addition to the determination of optimum WEDM parameters for surface roughness and material removal rate, the response table for the Taguchi method was used to calculate the average grey relational grade for each level of the WEDM parameters. The grey relational grade values for each level of the WEDM parameters were calculated using the same method. The grey relational grade values are shown in Table 8. Since the grey relational grade represents the level of correlation between the reference sequence and the comparability sequence, the greater value of the grey relational grade means that the comparability sequence has a stronger correlation to the reference sequence.

In other words, regardless of category of the performance characteristics, a greater grey relational grade value corresponds to better performance. Therefore, the optimal level of the machining parameters is the level with the greatest grey relational grade value. An asterisk (*) indicates that the level value results in a better machining performance.

Based on the grey relational grade values given in table 7 , the optimal machining performance for both the surface roughness and the material removal rate was obtained as pulse on time $116 \mu$ s (level 3), pulse off time $45 \mu$ s (level 1), wire feed rate $3 \mathrm{~mm} / \mathrm{min}$ (level 3)and servo control $80 \%$ (level 3) as best combination. The optimal WEDM parameters levels can be shortly given as A3, B1, C3 and D3.

The optimum value obtained are 0.312 for pulse on time, 0.283 for pulse off time, 0.300 for wire feed rate and 0.297 for servo control. The most effective factor affecting performance characteristics is determined by comparing these values. These comparisons will give the level of significance of the controllable factors over the multi- performance characteristics. The most effective controllable factor was the maximum of these values.

\section{B. Genetic Algorithm}

In genetic algorithm by using Minitab 17 software the regression equation is generated with the helping of input parameters. Regression equation obtained for surface roughness

$\mathrm{Ra}=-14.28+0.1472 * \mathrm{X}(1)-0.0070 * \mathrm{X}(2)+0.0133 * \mathrm{X}(3)-$ $0.236 * \mathrm{X}(4)$

Regression Equation for cutting speed

$\mathrm{VC}=-10.53+0.115 * \mathrm{x}(1)+0.0045 * \mathrm{x}(2)$ -

$.0037 * x(3)+0.037 * x(4)$

Where $\quad X(1)=$ pulse on time,
$\mathrm{X}(2)=$ pulse off time
$\mathrm{X}(3)=$ servo control,
$\mathrm{X}(4)=$ wire feed rate

For multi response optimization the regression equations of surface roughness and cutting speed are combined. To get multi response regression equation the individual regression equation is multiplied with weight values $\mathrm{W} 1$ and $\mathrm{W} 2$.
Where $\mathrm{W} 1=\mathrm{W} 2=0.5$
$\mathrm{W} 1 * \mathrm{Ra}=-7.14+0.0736 * \mathrm{X}(1)$
$0.0035 * \mathrm{X}(2)+0.00665 * \mathrm{X}(3)-0.118 * \mathrm{X}(4)$
$\mathrm{W} 2 * \mathrm{Vc}=-5.265+.0575 * \mathrm{X}(1)+0.00225 * \mathrm{X}(2)-$
$0.00185 * \mathrm{X}(3)+0.0185 * \mathrm{X}(4)$
Regression equation for multi response
$\mathrm{W} 1 * \mathrm{Ra}-\mathrm{W} 2 * \mathrm{Vc}=-1.875+0.0161 * \mathrm{X}(1)$ - $0.00575 * \mathrm{X}(2)+0.0085 * \mathrm{X}(3)-0.1365 * \mathrm{X}(4)$

These regression equations are copied in the MATLAB software. In MATLAB the script files are written to the regression equations. Genetic algorithm technique is selected by using optimtool code in MATLAB software. The multi objective optimization is done for both surface roughness and cutting speed by combining corresponding regression equations. The optimal process parameters are given in table 9 .

\begin{tabular}{|c|c|c|c|c|}
\hline $\begin{array}{l}\text { S. } \\
\text { No }\end{array}$ & $\begin{array}{l}\text { Pulse on } \\
\text { time }(\mu \mathrm{s})\end{array}$ & $\begin{array}{l}\text { Pulse off } \\
\text { time }(\mu \mathrm{s})\end{array}$ & $\begin{array}{c}\text { Wire feed rate } \\
(\mathrm{m} / \mathrm{min})\end{array}$ & $\begin{array}{c}\text { Servo } \\
\text { control }(\%)\end{array}$ \\
\hline 1 & 108 & 55 & 3 & 60 \\
\hline
\end{tabular}

The confirmation test was conducted to verify the accuracy of the analysis. The confirmation experiment was conducted at optimum combinations; the response values obtained are as follows: surface roughness $=1.4572$, cutting speed $=3.42$.

TABLE 10. : ResUlts OF MULTI OBJeCtive OPTIMIZATION OF WEDM

\begin{tabular}{|c|c|c|c|c|c|c|}
\hline \multicolumn{7}{|c|}{ PROCESS } \\
\hline $\begin{array}{c}\text { Optimizat } \\
\text { ion } \\
\text { method }\end{array}$ & $\begin{array}{c}\text { Performa } \\
\text { nce } \\
\text { paramete } \\
\mathbf{r}\end{array}$ & $\begin{array}{c}\text { Pul } \\
\text { se } \\
\text { on } \\
\text { tim } \\
\text { e } \\
(\mu \mathrm{s})\end{array}$ & $\begin{array}{c}\text { Pul } \\
\text { se } \\
\text { off } \\
\text { tim } \\
\text { e } \\
(\mu s)\end{array}$ & 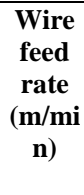 & $\begin{array}{c}\text { Serv } \\
\text { o } \\
\text { contr } \\
\text { ol } \\
(\%)\end{array}$ & $\begin{array}{c}\text { Optimu } \\
\text { m } \\
\text { value }\end{array}$ \\
\hline \multirow[t]{2}{*}{ GRA } & $\mathrm{Ra}$ & \multirow[t]{2}{*}{116} & \multirow[t]{2}{*}{45} & \multirow[t]{2}{*}{3} & \multirow[t]{2}{*}{80} & 2.5875 \\
\hline & $\mathrm{Vc}$ & & & & & 3.03 \\
\hline \multirow[t]{2}{*}{ GA } & $\mathrm{Ra}$ & \multirow[t]{2}{*}{108} & \multirow[t]{2}{*}{55} & \multirow[t]{2}{*}{3} & \multirow[t]{2}{*}{60} & 1.4572 \\
\hline & $\mathrm{Vc}$ & & & & & 3.42 \\
\hline
\end{tabular}

From the table 10 by using GRA the optimal values obtained are: surface roughness is 2.5875 and cutting speed is 3.03 at machining conditions of pulse on time $116 \mu \mathrm{s}$, pulse off time $45 \mu \mathrm{s}$, wire feed rate $3 \mathrm{~m} / \mathrm{min}$ and servo control $80 \%$, by using GA the optimal values obtained are: surface roughness is 1.33 and cutting speed is 3.42 at machining conditions of pulse on time $108 \mu \mathrm{s}$, pulse off time $55 \mu \mathrm{s}$, wire feed rate $3 \mathrm{~m} / \mathrm{min}$ and servo control $60 \%$

\section{CONCLUSIONS}

Wire electric discharge machining were conducted on AISI D3 material with varying four parameters such as pulse on time, pulse off time, wire feed rate and servo control, the important conclusions are the following ones: 
a) Factors like pulse on time, pulse off time, wire feed rate and spark gap voltage have been found to play a significant role in rough cutting operations for minimization of surface roughness and maximization of cutting speed.

b)By using GRA the optimal values obtained are: surface roughness is 2.5875 and cutting speed is 3.03.

c) By using GA the optimal values obtained are: surface roughness is 1.4572 and cutting speed is 3.42 .

d) The surface roughness value decreased by $43.68 \%$ and cutting speed value increased by $12.87 \%$. It shows that GA gives the best optimal values as compared to GRA

\section{REFERENCES}

[1] Brajesh Kumar Lodhi, Sanjay Agarwal "Optimization of Machining Parameters in WEDM of AISI D3 steel using Taguchi Technique" Procedia CIRP 14 (2014) 194-199.

[2] Jyoshana Joshi and Onkar Sonare "Optimization of wire EDM process parameters on D3 tool steel using principal component analysis" International Journal of mechanical and production engineering research and development (2017) 31-40.

[3] Shivade, Anand S "Multi-objective optimization in WEDM of D3 tool steel using integrated approach of Taguchi method \& Grey relational analysis" Journal of Industrial Engineering International (2014) 149-162.

[4] Pankaj R. Patill, P.M.Solanki " Effects of Machining Parameters on Tool Steel D2 in Wire cut EDM" IOSR Journal of Mechanical and Civil Engineering (2017) 12-19.

[5] M Siva Kumar, K Sivakumar "Parameters Optimization of Wire Electrical Discharge Machining on AISI D3 Steel with Different Thickness" International Journal of Applied Engineering Research, ISSN 0973-4562 Vol. 10 No.62 (2015).

[6] Omkar Kulkarni, Shalaka Kulkarni "Process Parameter Optimization in WEDM by Grey Wolf Optimizer" Materials Today: Proceedings 5 (2018) 4402-4412.

[7] Mangesh R. Phate, Shraddha B. Toney "Modeling and prediction of WEDM performance parameters for $\mathrm{Al} / \mathrm{SiCp}$ MMC using dimensional analysis and artificial neural network" Engineering Science and Technology, an International Journal (2018).

[8] C.D. Shah, J.R.Mevada "Optimization of Process Parameter of Wire Electrical Discharge Machine by Response Surface Methodology on Inconel-600" International Journal of Emerging Technology and Advanced Engineering (2013) ISSN 2250-2459.

[9] J.Udaya Prakash, S.Jebarose Juliyana "Optimization of Wire EDM Process Parameters for MachiningHybrid Composites (356/B4C/Fly Ash) using Taguchi Technique" Materials Today: Proceedings 5 (2018) 7275-7283.
[10] Ms. Shalaka Kulkarni, ManikRodge "PROCESS Parameter Optimization in WEDM of Hchcr Steel Using Taguhi Method and Utiltiy Concept" International Journal of Mechanical Engineering and Technology (2014) ISSN 0976 - 6359.

[11] Vinod Kumar, Vikas Kumar and Kamal Kumar Jangra, "An experimental investigation and statistical modelling for trim cutting operation in WEDM of Nimonic-90", International Journal of Industrial Engineering Computations 6 (2015) 351-364.

[12] Susanta Kumar Gauri, Shankar Chakraborty "Multi-response optimization of WEDM process using principal component analysis" Int J Adv Manuf Technol (2009) 41:741-748.

[13] Pratik A. Patil, C.A. Waghmare, "Optimization of process parameters in wire-edm using response surface methodology." Proceedings of 10th IRF International Conference, 01st June-2014, pp. 110-115.

[14] M. Durairaj, D. Sudharsun, N. Swamynathan, "Analysis of Process Parameters in Wire EDM with Stainless Steel using Single Objective Taguchi Method and Multi Objective Grey Relational Grade." Procedia Engineering 64 (2013), pp. 868-877.

[15] AmiteshGoswami, Jatinder Kumar, "Trim cut machining and surface integrity analysis of Nimonic $80 \mathrm{~A}$ alloy using wire cut EDM", Engineering Science and Technology, an International Journal 20 (2017) 175-186.

[16] Somvir Singh Nain, Dixit Garg, Sanjeev Kumar, "Modeling and optimization of process variables of wire-cut electric discharge machining of super alloy Udimet-L605", Engineering Science and Technology, an International Journal 20 (2017) 247-264. 